TALES FROM THE LONG TWELFTH CENTURY 

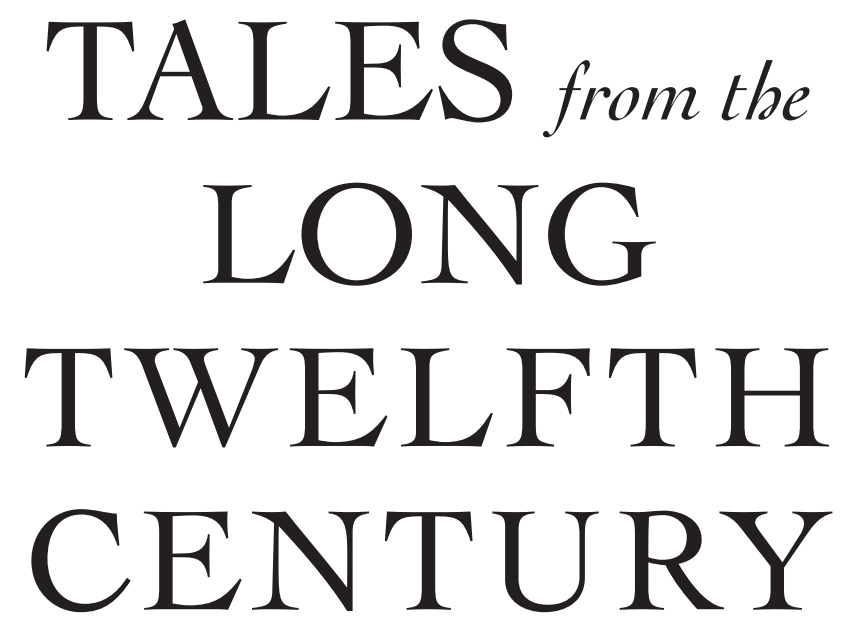

The Rise and Fall of the Angevin Empire

\section{RICHARD HUSCROFT}


Copyright (C) 2016 Richard Huscroft

All rights reserved. This book may not be reproduced in whole or in part, in any form (beyond that copying permitted by Sections 107 and 108 of the U.S. Copyright Law and except by reviewers for the public press) without written permission from the publishers.

For information about this and other Yale University Press publications, please contact:

U.S.Office: sales.press@yale.edu www.yalebooks.com

Europe Office: sales@yaleup.co.uk www.yalebooks.co.uk

Set in Adobe Caslon Pro by IDSUK (DataConnection) Ltd

Printed in Great Britain by Gomer Press, Llandysul, Ceredigion, Wales

Library of Congress Cataloging-in-Publication Data

Names: Huscroft, Richard, author.

Title: Tales from the long twelfth century : the rise and fall of the Angevin Empire / Richard Huscroft.

New Haven : Yale University Press, [2016] | Includes bibliographical references.

LCCN 2015035080 | ISBN 9780300187250 (alk. paper)

LCSH: Great Britain-History-Angevin period, 1154-1216. | Anjou,

House of. | Great Britain-History-12th century.

Classification: LCC DA205 .H87 2016 | DDC 942.03/1—dc23

$\mathrm{LC}$ record available at http://lccn.loc.gov/2015035080

A catalogue record for this book is available from the British Library.

$\begin{array}{llllllllll}10 & 9 & 8 & 7 & 6 & 5 & 4 & 3 & 2 & 1\end{array}$

iv 